\title{
Indirect spectrophotometric method for the determination of bisacodyl in commercial dosage forms and in environmental water samples
}

\author{
Nief Rahman Ahmad*, Nawal A. Majid** \\ *Department of Environmental Technology, College of Environmental, University of Mosul, Mosul, Iraq \\ **The State Company for Drug Industries and Medical Appliances, Mosul, Iraq.

\begin{tabular}{ll} 
Received & Accepted \\
\hline 27.3 .2011 & 3.7 .2011
\end{tabular}

\begin{abstract}
Objective: A simple, sensitive, and accurate indirect spectrophotometric method for the determination of bisacodyl in pure form and in some of its pharmaceutical preparations.

Method: The method is based on the oxidation of bisacodyl by iron (III), and subsequent complexation of iron (II) with o-phenanthroline.

Results: Forming a red-colored complex (ferroin) having the maximum absorbance at $510 \mathrm{~nm}$. Beer's law is obeyed in the concentration range of $0.5-5 \mu \mathrm{g} / \mathrm{ml}$. The molar absorptivity and sandell's sensitivity were $1.55 \times 10^{4} \mathrm{~L} \cdot \mathrm{mol}^{-1} . \mathrm{cm}^{-1}$ and $0.0233 \mu \mathrm{g} . \mathrm{cm}^{-2}$ respectively. The relative standard deviation (RSD) was less than $1.5(n=11)$. The limits of detection and quantitation are 0.083 and $0.25 \mu \mathrm{g} \cdot \mathrm{ml}^{-1}$ respectively.

Conclusion: The method is applied successfully for determination of bisacodyl in environmental water samples and in some pharmaceutical formulations (tablets and suppositories). A statistical comparison of these results with those of official method shows good agreement and indicates no significant difference in the precision.
\end{abstract}

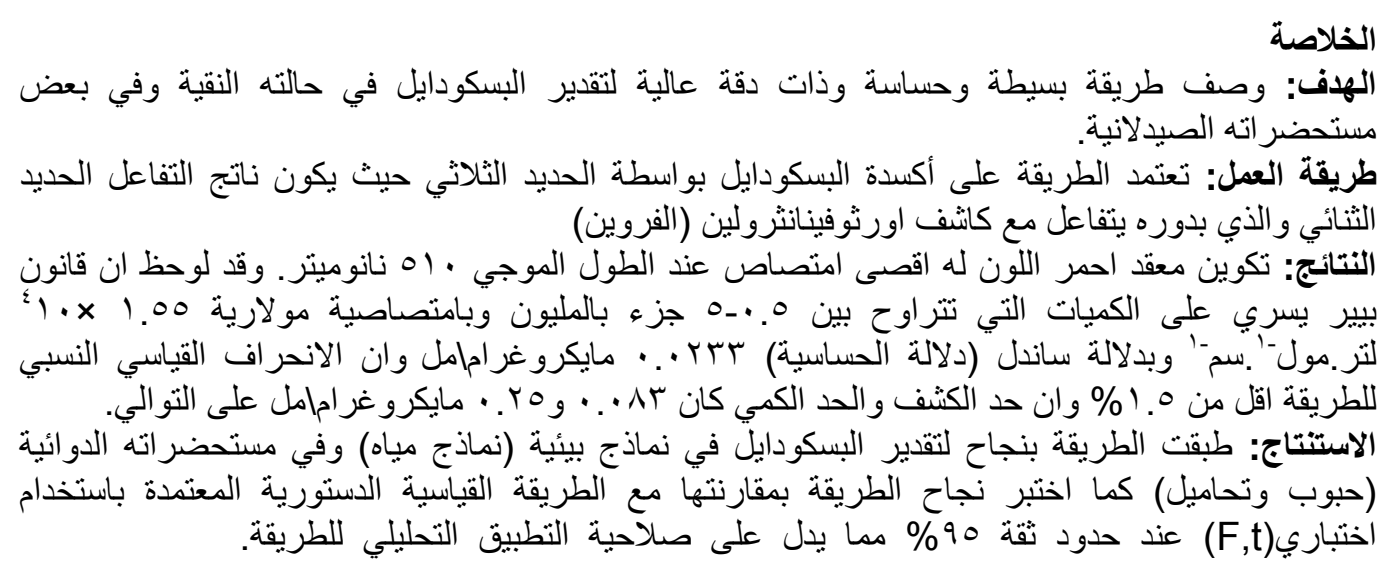

B isacodyl is $4,4^{\prime}$ (pyrid - $2-\mathrm{yl}$ methylene) bis (phenyl acetate) $\left[\mathrm{C}_{22} \mathrm{H}_{19} \mathrm{NO}_{4}=361.4\right]$ is a laxative used for the treatment of constipation, for evacuation of the colon before radiological examination of the abdomen, or endoscopy, and before or after surgical operations. It has little or no action on the small intestine. Doses of 5 to 10 milligrams may be given by mouth and act within 6 to 12 hours. Suppositories of 10 milligrams given by rectum act within one hour. Children under 10 years may be given 5 milligrams by mouth or by rectum ${ }^{1-4}$.

The literature survey reveals that only few methods have been reported for determination of Bisacodyl in pure 
form and in pharmaceutiacal formulations $^{5-11}$. Official method includes potantiometric titration for pure form and UV spectrophotometric method for tablets and suppositories ${ }^{5}$.

The spectrophotometric method include charge transfer and ion-pair complexation reaction ${ }^{6}$. Other methods reported for determination of bisacodyl like stability-indicating methods ${ }^{7}$, high-performance liquid chromatography ${ }^{8}$, high performance thin-layer chromatography ${ }^{9}$, memberane sensor ${ }^{10}$ and square-wave voltammetry $^{11}$. The present work describes a new, simple indirect, spectrophotometric method for the determination of bisacodyl in pure form, pharmaceutical formulations and in water samplels. The method is based on the reaction of drug with ferric chloride and 1,10-phenanthroline at $\mathrm{pH}$ 3 resulting in the formation of ferroin, which absorbs maximally at $510 \mathrm{~nm}$.

\section{Experimental}

\section{Apparatus}

Spectro-scan 50 UV- visible (double beam) spectrophotometer with $1.0 \mathrm{~cm}$ quartz cells was used for absorption measurements, and Jenway $3310 \mathrm{pH}$ meter was used.

\section{Reagents}

All chemical used were of analytical or pharmaceutical grade and distilled water was used throughout.

Bisacodyl stock solution (Nineveh drug industry,NDI): $100 \mathrm{ppm}$, this solution was prepared by dissolving $0.01 \mathrm{~g}$ of pure bisacodyl in $100 \mathrm{ml} 0.01$ $\mathrm{N} \mathrm{HCl}$ solution.

Bisacodyl standard solution (25 ppm) $\left(6.9 \times 10^{-5} \mathrm{M}\right)$, this solution was prepared by diluting $25 \mathrm{ml}$ of the stock solution to $100 \mathrm{ml}$ by $0.01 \mathrm{~N} \mathrm{HCl}$ in a volumetric flask.

Ferric chloride solution: $0.1 \%$, this solution was prepared by dissolving $0.1 \mathrm{~g}$ of ferric chloride in $100 \mathrm{ml}$ distilled water containing $2 \mathrm{ml}$ of concentrated $\mathrm{HNO}_{3}$. 1,10-phenanthroline solution: $1 \%$, this solution was prepared by dissolving $1 \mathrm{~g}$ of 1,10-phenanthroline in $10 \mathrm{ml}$ of ethanol, then the volume completed to $100 \mathrm{ml}$ with distilled water.

Buffer solution ( $\mathrm{pH} 3)$, this solution was prepared by mixing 16.2 $\mathrm{ml}$ of $0.1 \mathrm{M}$ chloroacetic acid with 8.8 $\mathrm{ml}$ of $0.1 \mathrm{M} \mathrm{KOH}$, then the volume was completed to $100 \mathrm{ml}$ with distilled water in a volumetric flask ${ }^{12}$.

\section{Recommended procedure}

A known volume of sample containing 12.5-125 $\mu \mathrm{g}$ of bisacodyl was transferred into a $25 \mathrm{ml}$ calibrated flasks followed by addition of $1 \mathrm{ml}$ of ferric chloride solution then $2 \mathrm{ml}$ of buffer solution $\mathrm{pH} 3$.The solution was mixed well and then heated in a water bath at $70 \pm 2{ }^{\circ} \mathrm{C}$ for $15 \mathrm{~min}$. The content of each flask were cooled at room temperature and $5 \mathrm{ml}$ of 1,10 phenanthroline solution was added. Finally the solution was diluted to the mark with distilled water, the absorbance of the red-colored products was measured at $510 \mathrm{~nm}$ against a reagent blank.

Analysis of pharmaceutical formulations

Ten tablets of bisacodyl were finely powdered and portion equivalent to 2.5 $\mathrm{mg}$ of bisacodyl was weighed accurately and stirred well with $3 \times 10$ $\mathrm{ml}$ portions of chloroform. The residue was filtered using whatman No.42 filter paper. The filtrate was evaporated to dryness and the residual drug was dissolved in $0.01 \mathrm{~N} \mathrm{HCl}$ and transferred to a $100 \mathrm{ml}$ standard volumetric flask which was then filled to volume with $0.01 \mathrm{~N} \mathrm{HCl}$. Treate 3 $\mathrm{ml}$ of this solution as mentioned under recommended procedure.

Weight five suppositories, transfer to a porcelin dish, melt and allow to cool while stirring with glass rod. Accurately weight a portion of the melted suppository mass, equivalent to 
$2.5 \mathrm{mg}$ of bisacodyl, extract with $3 \times 10$ $\mathrm{ml}$ portions of hot $0.01 \mathrm{~N} \mathrm{HCl}$, cool and the residue was filtered. The filtrate was transferred to a $100 \mathrm{ml}$ standard volumetric flask which was then filled to volume with $0.01 \mathrm{~N} \mathrm{HCl}$. Treate $3 \mathrm{ml}$ of this solution as described under recommended procedure.

Environmental water samples

Distilled and tap water samples $(100 \mathrm{ml})$ were fortified with $2.5 \mathrm{mg}$ of bisacodyl. The fortified water samples were analyzed as described under recommended procedure.

\section{Results and discussion}

The method is based on the oxidation of bisacodyl by iron III in presence of o-phenanthroline in acidic medium. The iron(II) formed was quantitively and rapidly converted to the stable tris (o-phenanthroline) iron II complex (ferroin) having an absorption maximum at $510 \mathrm{~nm}^{13,14}$ as shown in Figure 1, thus permitting the indirect determination of bisacodyl.<smiles>CC(=O)Oc1ccc(C(c2ccc(OC(C)=O)cc2)c2ccc(OC(C)=O)cc2)cc1</smiles>

$\mathrm{FeCl}_{2}+3 \mathrm{O}$-Phenanthroline $\longrightarrow \quad \mathrm{Fe} / 3 \mathrm{O}-$ Phenanthroline $+2 \mathrm{Cl}^{-}$

Figure 1. Oxidation of bisacodyl

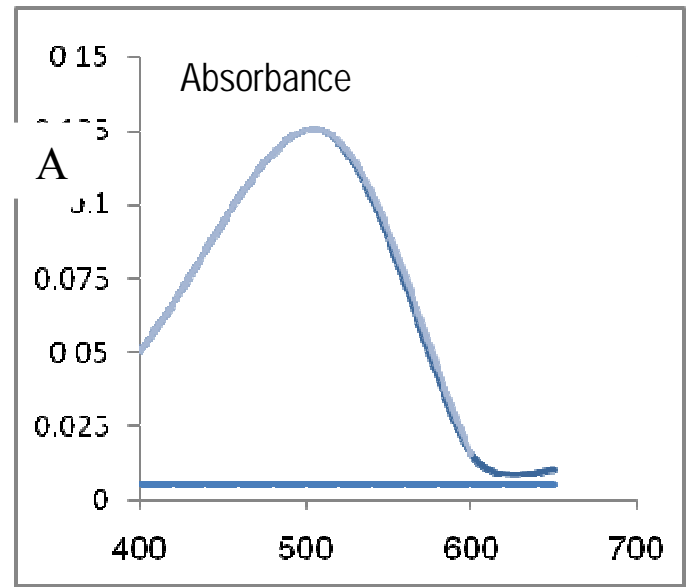

Figure 2. Absorbance spectra of A: bisacodyl. B: blank 
Fig 2 Absorption spectra of A: $3 \mu \mathrm{g}$ $/ \mathrm{ml}$ of bisacodyl with $\mathrm{FeCl}_{3}$ and Ophenanthroline against reagent blank. B: blank against distilled water.The reaction variables were optimized by varying each variable while keeping other constants for obtaining maximum absorbance. The oxidation reaction was found to be quantitative in acidic medium, the $\mathrm{pH} 2.0-4.0$ was considered optimum. Then, a $\mathrm{pH}$ of 3.0 was selected for the subsequent experiment. Four types of buffer solution $\mathrm{pH} 3$ of different composition 15 have been tested for this purpose. Table [1] shows the results of this investigation.

1-3 $\mathrm{ml}$ of buffer B4 gave high sensitivity and $2 \mathrm{ml}$ have been used for subsequent experiment. The effect of $\mathrm{FeCl} 3$ and o-phenanthroline amounts on the absorbance was investigated . A maximum and constant absorbance was found with $2 \mathrm{ml} \mathrm{FeCl}_{3}$ and $5 \mathrm{ml}$ of $1 \%$ o-phenanthroline, which were therefore adopted as being optimal. The color reaction occurred even at room temperature $\left(25^{\circ} \mathrm{C}\right)$, though at higher temperature the color developed more rapidly, the maximum absorbance was observed after $15 \mathrm{~min}$ of heating the solution at $70^{\circ} \mathrm{C}$. A stemperature of $70^{\circ} \mathrm{C}$ and a reaction time of $15 \mathrm{~min}$ were selected for reproducible results. Under the experimental conditions described Beer's law is obeyed over the concentration range $0.5-5 \mu \mathrm{g} \cdot \mathrm{ml}^{-1}$ (Figure 3). Linear regression equation: $\mathrm{A}=0.01+0.04 \mathrm{C}(\mathrm{r}=0.999 \mathrm{n}=10)$, where $\mathrm{A}$ is the absorbance and $\mathrm{C}$ is concentration in $\mu \mathrm{g} / \mathrm{ml}$. The apparent molar absorptivity was $1.55 \times 10^{4} 1 . \mathrm{mol}^{-}$ ${ }^{1} . \mathrm{cm}^{-1}$ and sandell's sensitivity was $0.0233 \mu \mathrm{g} . \mathrm{cm}^{-2}$. The limit of detection and quantification were evaluated as ${ }^{16}$.

$$
\mathrm{LOD}=3.3 \frac{s_{0}}{b} \quad \text { LOQ }=3 \mathrm{LOD}
$$

Where $\mathrm{b}$ is the slope and $S_{0}$ is the standard deviation of the regression line. The limit of detection was 0.083 $\mu \mathrm{g} . \mathrm{ml}^{-1}$ and the limit of quantification as the lowest standard concentration which could be determined with acceptable accuracy, and precision was $0.25 \mu \mathrm{g} \cdot \mathrm{ml}^{-1}$.

Table 1. Effect of different buffers on the absorbance

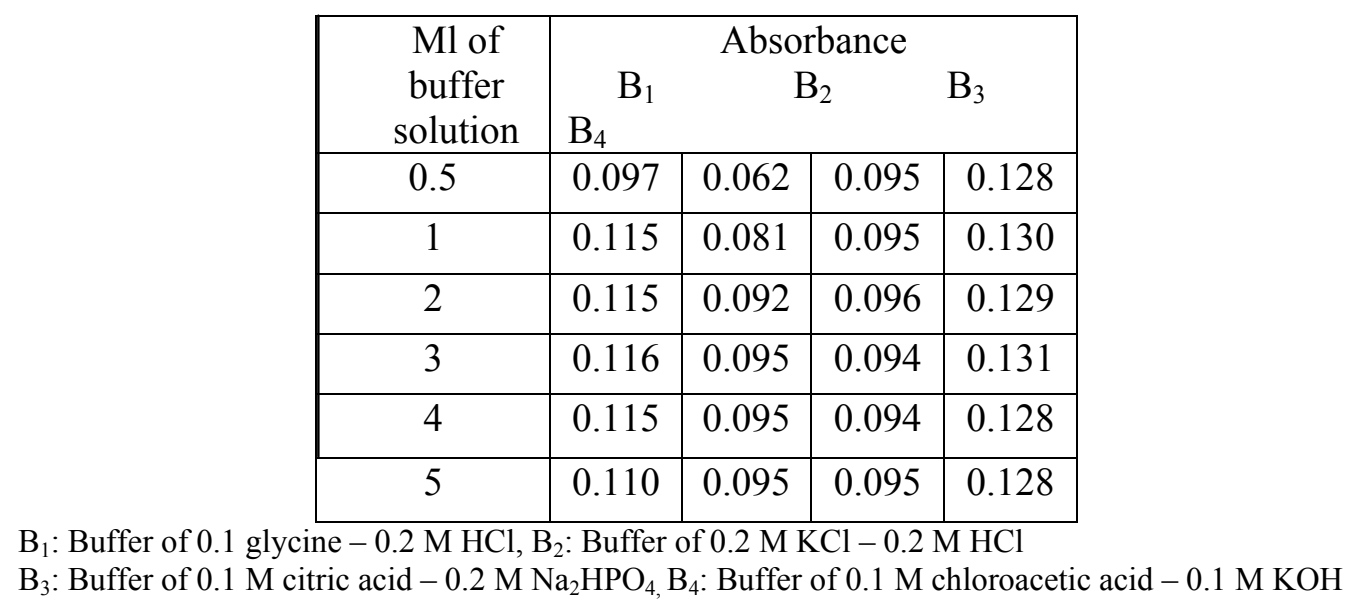




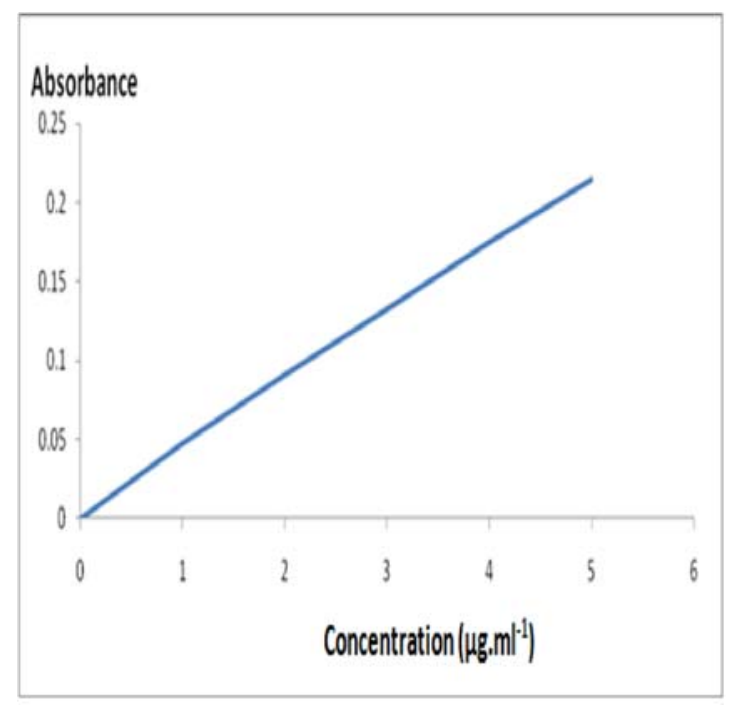

Figure 3. Calibration graph of bisacodyl

Table 2. Optical characteristics and statistical data for regression equation of the proposed method

\begin{tabular}{|c|c|}
\hline Parameters & Value \\
\hline$\lambda \max (\mathrm{nm})$ & 510 \\
\hline $\mathrm{pH}$ & 3.0 \\
\hline Beer's law limits $\left(\mu \mathrm{g} \cdot \mathrm{ml}^{-1}\right)$ & $0.5-5$ \\
\hline Molar absorptivity $\left(\mathrm{L} \cdot \mathrm{mol}^{-1} \cdot \mathrm{cm}^{-1}\right)$ & $1.55 \times 10^{4}$ \\
\hline Limit of detection $\left(\mu \mathrm{g} \cdot \mathrm{ml}^{-1}\right)$ & 0.083 \\
\hline Limit of quantification $\left(\mu \mathrm{g} \cdot \mathrm{ml}^{-1}\right)$ & 0.25 \\
\hline Sandell's sensitivity $\left(\mu \mathrm{g} . \mathrm{cm}^{-2}\right)$ & 0.0233 \\
\hline Correlation coefficient (r) & 0.999 \\
\hline \multicolumn{2}{|l|}{ Regression equation $(\mathrm{A}=+\mathrm{bc})$} \\
\hline Intercept ( ) & 0.01 \\
\hline Slope (b) & 0.04 \\
\hline Recovery & $100 \pm 0.89$ \\
\hline Relative standard deviation (\%) & $<1.5$ \\
\hline
\end{tabular}

\section{Accuracy and precision}

The accuracy and precision of the method were established by analyzing the pure drug solution at three different levels. The average recovery which is a measure of accuracy is $100 \pm 0.89 \%$ revealing high accuracy of the method. The relative standard deviation (RSD), which is an indicator of precision, was less than $1.5 \%$, the result are complied in Table 2.

Interferences

A study of interference of some common excipients has been made during determination of $3.0 \mu \mathrm{g} . \mathrm{ml}^{-1}$ bisacodyl. It was observed that starch, glucose and lactose could be tolerated with a maximum amount of $12.0 \mathrm{mg}$, $20 \mathrm{mg}$ and $55 \mathrm{mg}$ respectively. However the drug content from powdered tablets was extracted with chloroform, which completely eliminates any interference by the common excipients found in drug formulations. Thus, the stability 
of the proposed method indicates that it can be used for the analysis of bisacodyl in drug formulations in the presence of various excipients found in the suppositories and tablets.

\section{Application of the proposed method}

The proposed method was successfully applied for the determination of bisacodyl in pharmaceutical formulations and environmental water samples.

Table 3 of the proposed method were compared with those of official method 5, using student t-test and variance ratio $\mathrm{F}$-test at $95 \%$ confidence level. The calculated $t$ and $F$ values did not exceed the theoretical value indicting that there was no significant difference between the precision of the proposed and official method. It was also evident from the table that the results of bias (lower and upper limits) based on recovery experiments of the proposed method are acceptable (with the range of $\pm 2 \%$ ). The Canadian health protection branch has recommended a bias of $\pm 2 \%\left(\mathrm{Q}_{\mathrm{L}}=\right.$ 0.98 and $\mathrm{Q}_{\mathrm{u}}=1.02$ ) in the pharmaceutical analysis, which was based on recovery experiment of the developed method ${ }^{17}$ and the results of water samples Table 4 showed that the recovery values obtained were close to $100 \%$.

Table 3. Determination of bisacodyl in pharmaceutical preparations

\begin{tabular}{|c|c|c|c|c|c|c|}
\hline \multirow{2}{*}{\begin{tabular}{|l|} 
Pharmaceutical preparation \\
\end{tabular}} & \multicolumn{4}{|c|}{ Amount of bisacodyl * } & \multirow{2}{*}{$\begin{array}{c}\mathrm{t} \\
\text { value }\end{array}$} & \multirow{2}{*}{$\begin{array}{c}\mathrm{F} \\
\text { value }\end{array}$} \\
\hline & $\begin{array}{l}\text { Proposed } \\
\text { method }\end{array}$ & metho & & official & & \\
\hline & $\begin{array}{l}\text { Amount } \\
\text { recovery } \\
5.03\end{array}$ & 100.6 & $\begin{array}{l}\text { Amount } \\
\text { recovery } \\
4.97\end{array}$ & 99.4 & 1.63 & 1.54 \\
\hline Bisacodyl tablets (10mg/tab) & 10.05 & 100.5 & 10.02 & 100.2 & 1.55 & 1.48 \\
\hline $\begin{array}{l}\text { Bisacodyl suppositories } \\
\text { (5mglsupp) }\end{array}$ & 5.01 & 100.2 & 5.02 & 100.4 & 1.98 & 1.18 \\
\hline $\begin{array}{l}\text { Bisacodyl suppositories (10 } \\
\text { mglsupp) }\end{array}$ & 10.05 & 100.5 & 10.08 & 100.5 & 1.88 & 1.26 \\
\hline
\end{tabular}

* Mean of ten determinations.

$T$ values ( $n=10$, at $95 \%$ confidence level tabulated value 2.262 ).

$\mathrm{F}$ values ( $\mathrm{n} 1$ and $\mathrm{n} 2=10$, at $95 \%$ confidence tabulated value 3.18 ). 
Table 4. Determination of bisacodyl in water samples

\begin{tabular}{|l|l|l|l|}
\hline Water Samples & Added $\mu \mathrm{g} / \mathrm{ml}$ & Found $\mu \mathrm{g} / \mathrm{ml}$ & Recovery \% \\
\hline Tap Water & 0.3 & 0.302 & 101 \\
& 1.0 & 0.99 & 99.00 \\
& 2.5 & 2.47 & 98.88 \\
\hline Distilled Water & 0.3 & 0.303 & 101 \\
& 1.0 & 0.98 & 98 \\
& 2.5 & 2.5 & 100 \\
\hline
\end{tabular}

Table 5. Content uniformity testing of metformin hydrochloride tablets using the proposed method.

\begin{tabular}{|l|l|}
\hline Parameter & \% of the label claim \\
\hline Tablet NO. 1 & 100.48 \\
Tablet NO. 2 & 100.25 \\
Tablet NO. 3 & 99.56 \\
Tablet NO. 4 & 100.52 \\
Tablet NO. 5 & 99.38 \\
Tablet NO. 6 & 99.35 \\
Tablet NO. 7 & 99.72 \\
Tablet NO. 8 & 100.03 \\
Tablet NO. 9 & 100.66 \\
Tablet NO. 10 & 99.71 \\
Mean (X ) & 100.73 \\
\% RSD & 0.54 \\
Max. allowed unit & $\pm 15 \%$ \\
\hline
\end{tabular}

\section{Application of the method to content uniformity}

The proposed method proved to be suitable for the content uniformity test, where a great number of assays on individual tablets are required. Data presented in Table 5 indicates that the proposed method can accurately and precisely quantitates bisacodyl in its commercially available tablets. The mean percentage (with RSD) of the labeled claim found in ten tablets was $(0.54 \%)$ which fall within the content uniformity limits specified by the USP $30^{18}$.

\section{Conclusion}

The proposed method was simple, accurate, precise, sensitive and low economical cost. Furthermore, the proposed method doesn't require elaboration of procedures, which are usually associated with chromatographic methods. The proposed method could be applied successfully for determination of bisacodyl in environmental water samples, pure form as well as in different dosage forms 


\section{References}

1. The pharmaceutical codex, London, 1979, P.105.

2. parfitt K, Blake SC, Parsons PS, Martindale AV; The Extra pharmacopoeia; $32^{\text {nd }}$ edition, pharmaceutical press: London, 2005 p1251.

3. Rachmilewitz D, Karmeli F, Okon E. Effect of bisacodyl on CAMP and Prostaglandin $\mathrm{E}_{2}$ content, $(\mathrm{Na}+\mathrm{k})$. ATP ase, adenyl clase, and phosphodiesterase activities of rat intestine. Dig Dis sci 1980;25(8) :602-607.

4. Remington: the science and practice of pharmacy, mack publisher company, Easton, pennsylvania 18042, 1995 volum 2 P.896.

5. British pharmacopiea, 2009, P. 724.

6. Mohamed H, Suzy M, Magda H, Tarek S, Spectrophotometric detemination of bisacodyl and piribedil. Analytical letters 2004;37(2):247-262

7. Fadia H, Abdelkawy M, Ibrahim A. Development and validation of three stability- indicating methods for determination of bisacodyl in pure form and pharmaceutical preparations. J AOAC int 2007;90 (1):113-127.

8. Laik SA. Detemination of bisacodyl and its hydrolysis products in bisacodyl formulations by high preformance liquid chromatography, Fresenius Z. Anal Chem 1979;299:124-126.

9. Campbell AN, Sherma J. Development and validation of a high performance thin-layer chromatographic method densitometric detection for determination of bisacodyl in pharmaceutical tablets. Acta chromatographica, 2003;13:109-

16.

10. Ramin M, Amir A, Jouyban A. Amembrane Sensor for selective determination of bisacodyl in tablets. J Chin Chemi Soc 2006; 53:613-18.

11. Parandis D, Parvz N, Reza GM. Rapid determination of bisacodyl in flow-injection system combination by a novel sensitive square-ware voltammetry. 2009;136(1):66-72.

12. Zommer-Urbanska S, Bojarowicz $\mathrm{H}$ Spectrophotometric investigation on protolytic equilibria of mefenamic acid and determination by means of $\mathrm{Fe}(\mathrm{III})$ in methanol-equeous media. J pharm Biomed Anal 1986;4:475-81.

13. MarezcenkoZ. Spectrophotometric determination of elements. Ellis worwood limited, chicheaster, 1976. p. 309-12.

14. Morrison RT, Boyed RN. s Organic chemistry. New York: Allyn and Bacon, INC, $3^{\text {rd }}$ edition, 1973, p. 1017.

15. Perrin DD, Dempsey B, Buffer for $\mathrm{pH}$ and metal ion control. London: Champan and Hall Ltd, 1974. p. 132-36

16. Basavaiah K, Somashekar BC. Quantitation of rantidine in pharmaceuticals by titrimetry and spectrophotometry using dichromate as the oxidimetric reagent. J Iran Chem Soc 2007; 4: 78-88

17. Canadian Health Protection Branch Gui deline-Acceptable method, Ministry of National Health and welfare. Canada Health protection Brand, Ottawa, Canada ,1992.

18. The United State Pharmacopeia Convection, Inc, 32 NF27, 2009, p. 382. 